\title{
Water and health risk assessment in the Aracaju Expansion Zone - SE
}

\author{
Ana Celia Goes Melo Soares \\ Rômulo André Santos Silva \\ Carla Viviane Freitas de Jesus \\ Roneval Felix Santana \\ Álvaro Silva Lima \\ Sonia Oliveira Lima \\ Maria Nogueira Marques
}

${ }^{I}$ Health and Environment, University of Tiradentes (Unit) Aracajú/SE - Brasil

(D) II Engineering and Environmental Sciences, Federal University of Sergipe (UFS).

São Cristóvão/SE - Brasil

(D) Health and Environment, University of Tiradentes (Unit) Aracajú/SE - Brasil

IV Health and Environment, University of Tiradentes (Unit) Aracajú/SE - Brasil

(D) ${ }^{V}$ Process Engineering, University of Tiradentes (Unit). Institute of Technology and Research (ITP) Aracajú/SE - Brasil

${ }^{V I}$ Health and Environment, University of Tiradentes (Unit). Institute of Technology and Research (ITP)

Aracajú/SE - Brasil

(D) VII Health and Environment, University of Tiradentes (Unit). Institute of Technology and Research (ITP)

Aracajú/SE - Brasil
Abstract: The Aracaju Expansion Zone presents problems related to lack of water in adequate conditions of quantity and quality. The low purchasing power of the local community has led residents to excavate shallow wells in their homes to ensure water supply, the only alternative for domestic consumption, but untreated. The objective of this work was to evaluate the quality of well water and the scenarios of health risk, through microbiological analyses. The collections were carried out in the period from December 2015 to August 2017, according to the methodology established by Standard Methods for the Examination of Water and Wastewater, 21st ed. It was concluded that in the rainy season, the well water presents contamination by coliforms, heterotrophic bacteria, Staphylococcus aureos and sulfite reducing bacteria, while in the dry season most of the samples did not present bacteriological counts

Keywords: Microbiological analysis, Public Health, Sergipe, Northeast.

São Paulo. Vol. 23, 2020

Original Article

DOI: http://dx.doi.org/10.1590/1809-4422asoc20170256r1vu2020L4AO 


\section{Introduction}

Water is part of the bodies of all living organisms; it is one of the Earth's natural resources, essential for the survival of human beings and therefore a highly valuable social and economic asset of extreme importance for the maintenance of life on the planet. It is also responsible for the transportation of substances that guarantee the process of a series of chemical reactions and is considered to be a universal solvent in view of its property of dissolving innumerable chemical compounds (UNESCO, 2015).

The fact that humans use it in so many ways has led to an increase in water consumption in recent years, accompanying urban and economic growth (CAPP et al., 2012). One important use of water is to quench the thirst of both humans and animals but for water to be potable, that is, suitable for human consumption, it must be free of any substances or organisms that might be a threat to their health.

According to a World Health Organization (WHO) and UNICEF report, 2.1 billion people on the planet do not have safe access to treated water in their homes and 4.5 million do not have water supply or sanitation. Even though that situation has been changing since the turn of the millennium and thousands of millions of people have gained access to water supply and sanitation, there is no guarantee that the water the respective services supply is potable and safe for health. Of the 2.1 billion mentioned above, 844 million do not have basic potable water supply and that includes 263 million people who spend at least 30 minutes walking to collect water from sources far from their homes and another 159 million who drink untreated water straight from sources such as rivers, lakes and others (WHO, 2017)

The same report also underscores how those factors and others heighten the risk of people catching diseases such as diarrhea that threaten their health, especially small children. Contaminated water and lack of sanitation are associated to the transmission of diseases such as cholera, dysentery, hepatitis A and typhoid fever (WHO, 2017).

Currently, Edict n ${ }^{\circ} 2914$, issued by the Brazilian Ministry of Health and published in the Official Gazette on December, 12, 2011, establishes the maximum acceptable values for certain physical, chemical and microbiological and radioactive parameters to guarantee the quality of water being supplied to the population.

Brazil has $12 \%$ of all the freshwater on the Planet but with a highly unequal distribution as $81 \%$ of it is concentrated in the Amazon basin, home to a mere $5 \%$ of the country's population. In the hydrographic regions washed by the Atlantic Ocean, where $45.5 \%$ of the population is concentrated, only $2.7 \%$ of the country's water resources are to be found (ANA, 2014). However, only $83.3 \%$ of Brazilians have a treated water supply which means that 35 million Brazilians do not have access to that basic service (BRASIL, 2017).

In spite of being a country with those difficult characteristics, there is widespread waste of water. Depending on the state of conservation of the distribution networks, from 20 to $30 \%$ of treated water being supplied for domestic consumption is lost in the distribution. Those losses occur mainly in the trajectory from the treatment stations to 
ism most commonly used worldwide as an indicator of fecal contamination (BARRELL et al., 2002; SOUZA, 2014; SILVA et al., 2015).

In response to the increasingly alarming reports concerning this precious natural resource, the regulatory legislation governing water has been progressively modified. Furthermore, the United Nations Organization regularly publishes its forecast/estimates regarding water in its World Water Development Report. Among the estimates is that "by 2030 , the world will be facing a $40 \%$ water deficit so that management of this resource must be improved" (UNESCO, 2015).

1.4 billion $\mathrm{km} 3$ of water cover $70 \%$ of the planet's surface and $97.5 \%$ of that volume is saltwater which is not used for consumption. It means that the percentage of water actually suitable for use is less than $3 \%$ of the total water. Of that $3 \%$, however, $71 \%$ of all freshwater is in a solid state in the glaciers and polar ice caps, $18 \%$ is in underground deposits, $7 \%$ in lakes and water courses and another $4 \%$ is in the form of humidity in the atmosphere. An important point to highlight is that the volume of freshwater is very unevenly distributed around the world (UNESCO, 2015).

In spite of Brazil's privileged position in the world in regard to the availability of water resources, there are considerable disparities among its regions. One example is the Northeast macro-region where there are areas with a water availability figure, in terms of water/inhabitant/year, well below the minimum recommended by the UN which is 2,000 liters. The various water situations in Brazil can be attributed to climate because forecasts are that there will be a reduction of $20 \%$ in rainfall in the North and Northeast of Brazil by the end of the 21st century (MARENGO, 2008).

The state of Sergipe situated in the northeast of Brazil is no different from the rest of the region in regard to the question of the quality of water for domestic supply. In regard to the capital city, Aracaju, and the preservation of the environment, it deserves special mention insofar as it is associated to a series of lakes (coastal lagoons and lakes associated to river courses) with various islands and islets close to the coast and, along the coast, remaining areas of Restinga (spitland) vegetation and mangrove swamps of great social and ecological importance.

The expansion zone (Zona de Expansão de Aracaju-ZEA) of the city of Aracaju, capital of the state of Sergipe, is located on the coast and is typified by a mixture of urban and rural features. Most of the local residents live around areas where there are septic tanks and open air waste dumps, constituting a potential source of contamination for both surface water and groundwater. In the same areas it is common to make use of shallow wells to obtain water for human consumption or to supplement the domestic supply (SOARES, 2012).

Given the existence of sanitation infrastructure problems in the ZEA such as lack of sewage treatment, use of septic tanks and the use of water from shallow wells, this study sought to conduct microbiological analyses of the well water in those areas of recent occupation and assess the health risks posed by the population's use of such water and its possible contamination. 


\section{Material and Methods}

Qualitative-quantitative research in the Expansion Zone of the state capital of Sergipe, Aracaju, located in the south of the city, around $13 \mathrm{~km}$ from the city center and occupying $40 \%$ of the total area of the municipality.

Ten collection points were selected based on the criterion that the respective residences depended on a well as their only source of domestic water supply, including water to drink. The microbiological quality of the water was evaluated for nine wells located in the research area and one located more than ten kilometers away which served as the control (Table 1). Samples were collected in the months of December 2015 (dry Period), April 2016, (rainy period), October 2016 (unseasonal rainy period), February 2017 (dry period) and August 2017 (rainy period).

Field trips were a made to get to know the area and delimit the wells to be analyzed (Table 1). All of them are shallow wells and all of them were in active use by the local population as sources of water to drink and for other domestic utilities.

\section{Table 1 - Identification of the Collecting Points and their co- ordinates (UTM, DATUM SIRGAS, 2000)}

\begin{tabular}{c|c|c}
\hline \multirow{2}{*}{$\begin{array}{c}\text { COLLECTION } \\
\text { POINTS }\end{array}$} & \multicolumn{2}{|c}{ UTM COORDINATES } \\
\hline P1 & $702921 \mathrm{mE}$ & $8775487 \mathrm{mS}$ \\
P2 & $702911 \mathrm{mE}$ & $8775489 \mathrm{mS}$ \\
P3 & $702866 \mathrm{mE}$ & $8775469 \mathrm{mS}$ \\
P4 & $702868 \mathrm{mE}$ & $8775448 \mathrm{mS}$ \\
P5 & $703000 \mathrm{mE}$ & $8775256 \mathrm{mS}$ \\
P6 & $702937 \mathrm{mE}$ & $8775175 \mathrm{mS}$ \\
P7 & $702925 \mathrm{mE}$ & $8775176 \mathrm{mS}$ \\
P8 & $702930 \mathrm{mE}$ & $8775216 \mathrm{mS}$ \\
P9 & $702852 \mathrm{mE}$ & $8775350 \mathrm{mS}$ \\
P10 & $710333 \mathrm{mE}$ & $8781526 \mathrm{mS}$ \\
\hline
\end{tabular}

Source: The Author.

Figure 1 shows the locations of the ten places where water samples were collected. The outlying tenth well is the control. The wells were georeferenced using a Garmin, model eTrex Vista HCx GPS apparatus. 
Figura 1 - Map showing the location of the collecting points

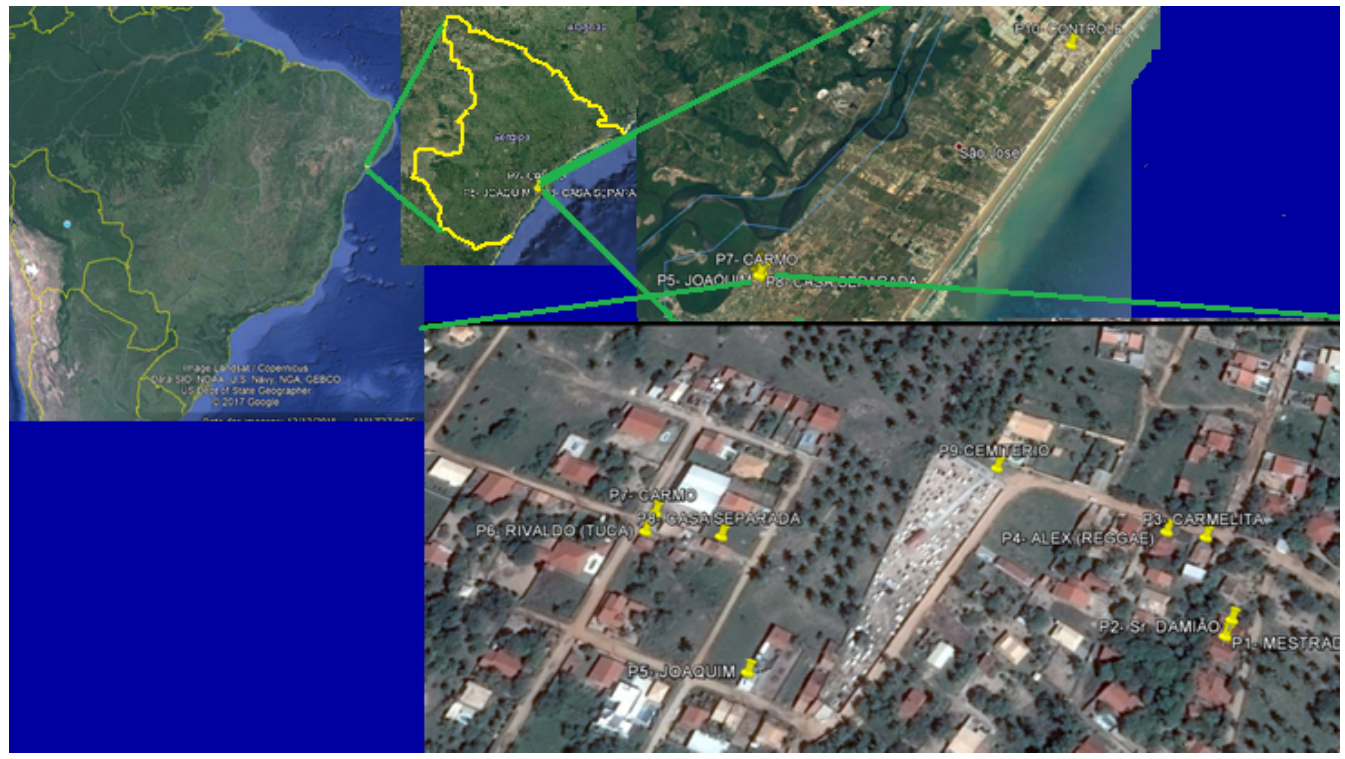

Source: Google Earth.

Water samples for microbiological analysis were collected in $250 \mathrm{ml}$ capacity glass vessels duly identified and previously sterilized in an autoclave. After collection the samples were placed in refrigerated thermal isolation containers for posterior laboratory analysis.

For the quantification of total coliforms and thermotolerant coliforms the research adopted the Most Probable Number (MPN) method and results were expressed in MPN/100mL. The method consists in quantifying the tubes that showed positive in the presumptive and confirmative tests. The quantifications obtained are then compared with the MPN reference table (APHA, 2012).

The water samples were collected and analyzed in accordance with the procedures of the Standard Methods for the Examination of Water and Wastewater (SMEWW) (2012) displayed in Table 2. They were stored in thermal insulation containers at a temperature of around $4^{\circ} \mathrm{C}$ (four degrees Celsius). The time between collection and arrival at the laboratory was never more than six hours to ensure the retarding of any biological action and the preservation of the organisms and to avoid any morphological or physiological alterations. 
Table 2 - Methodology adopted for analysis of water quality parameters, measurement units and method quantification limit.

\begin{tabular}{|c|c|c|c|}
\hline Microbiological Tests & Methods & Unit & LQ \\
\hline Total Coliforms & SMEWW 9221 & MPN & 1 \\
\hline $\begin{array}{c}\text { Thermotolerant } \\
\text { Coliforms }\end{array}$ & SMEWW 9221 & MPN & 1 \\
\hline $\begin{array}{c}\text { Thermotolerant } \\
\text { Salmonella }\end{array}$ & SMEWW 9260 & UFC & 1 \\
\hline Clostridium & SMEWW9260 & UFC & 1 \\
\hline $\begin{array}{l}\text { Heterotrophic Bacte- } \\
\text { ria Heterotrophic }\end{array}$ & SMEWW 9215 & UFC & 1 \\
\hline Staphylococcus aureus & SMEWW 9230 & UFC & 1 \\
\hline
\end{tabular}

Source: The Author.

Researchers conducted interviews with 10 residents of the households that use the shallow wells as their only source of water for domestic water supply. The interviews gleaned information on: 1) various aspects of the water consumed;2) the kind of water supply and the treatment given to solid waste and wastewater generated by the household; 3) the use made of the well water; 4) whether the residents associated sickness experienced by household members with the use of the well water; and 5) whether there were any household members belonging to the groups more susceptible to water-borne diseases (children under five and adults over 65, or others).

The University of Tiradentes Research and Ethics Committee duly approved the Research Project on May 2, 2011: process № 260411.

\section{Results and Discussion}

The shallow wells whose waters were analyzed were from 04 to 20 meters deep, and all of them had been dug by the residents themselves without any technical aspects being taken into account in their excavation, which is typical of well construction in the area. They are designed to capture water from the water table and pump it to the surface.

During the interviews that were part of the study methodology, the resident at point 5 , in response to question 1 commented that "the deeper the well, the less possibility there is of contamination from excreta in the soil" and that was indeed verified by the microbiological analyses that were performed (see Table 3). The well in his residence is 20 meters deep while most of the others range from 4 to 7 meters deep.

The responses to question 2 confirmed that all interviewees use well water for their domestic supply (one of the research's selection criteria) and also that there was a regular 
waste collection service (three times a week) but nevertheless some resident's threw their waste out in the open or burned it. They also said that their homes were not served by a sewage network and all the wastewater and sewage they generate is discharged directly into the environment.

In response to questions 3 and 4 the residents stated that the well water was their only source for domestic consumption and they did not associate its use to any diseases. The responses to question 5 showed that $50 \%$ of the households where interviews were conducted had either old people or children among their members but the respondents did not show any concern in regard to diseases affecting those particular age groups.

In the area in question there has been a lack of water supply for two decades which has made digging wells a common practice. The area overlies a water table and coastal sand soils that are propitious for digging shallow wells down to a depth of 20 meters. The consequence of that fact, together with the inadequate disposal of solid waste, sewage discharged into the environment, the presence of septic tanks and the social and cultural conditions of the local inhabitants is the contamination of the groundwater by pathogenic micro-organisms.

Sample collection took place in the period from December 2015 to August 2017. In $36 \%$ of the samples, analysis detected the presence of total and thermotolerant coliforms; in $13 \%$, the presence of heterotrophic bacteria; in 21\% Staphylococcus aureos was found and in $21 \%$, the presence of sulfite reducing bacteria. Thus the samples presented positive results for the presence of micro-organisms, especially in rainy periods.

Some of the sample collections do not appear in the table. That was because the residents were not at home at the time when the sample was supposed to be taken.

Table 3. Results of the microbiological analysis of underground water samples from the collection points in the period from December 2015 to August 2017

\begin{tabular}{|c|c|c|c|c|c|c|c|}
\hline $\begin{array}{l}\text { Points } \\
\text { DATES }\end{array}$ & $\begin{array}{l}\text { Thermo- } \\
\text { tolerant } \\
\text { Coliforms }\end{array}$ & $\begin{array}{c}\text { Total } \\
\text { Coliforms }\end{array}$ & Salmonella & Clostridium & $\begin{array}{l}\text { Hetero- } \\
\text { trophic } \\
\text { bacteria }\end{array}$ & $\begin{array}{l}\text { Stafhylo } \\
\text { coccus } \\
\text { aureus }\end{array}$ & $\begin{array}{l}\text { Sulfite } \\
\text { reducing } \\
\text { Bactéria }\end{array}$ \\
\hline Units & \multicolumn{2}{|l|}{ MPN/100mL } & \multicolumn{5}{|l|}{$\mathrm{CFU} / \mathrm{mL}$} \\
\hline P1D-12/15 & $\mathrm{NC}$ & NA & $\mathrm{NC}$ & $\mathrm{NC}$ & $\mathrm{NC}$ & $(-)$ & $\mathrm{NC}$ \\
\hline P1D-04/16 & $\mathrm{NC}$ & NA & $\mathrm{NC}$ & $\mathrm{NC}$ & $\mathrm{NC}$ & $(-)$ & $\mathrm{NC}$ \\
\hline P1R-10/16 & 21 & 80 & $\mathrm{NC}$ & $\mathrm{NC}$ & 380 & $\mathrm{NC}$ & 130 \\
\hline P1R-02/17 & $<1$ & $<1$ & $\mathrm{NC}$ & $\mathrm{NC}$ & $\mathrm{NC}$ & $\mathrm{NC}$ & $\mathrm{NC}$ \\
\hline P1R-08/17 & $<1$ & $<1$ & $\mathrm{NC}$ & $\mathrm{NC}$ & 100 & $\mathrm{NC}$ & $\mathrm{NC}$ \\
\hline P2D-12/15 & $\mathrm{NC}$ & NA & $\mathrm{NC}$ & $\mathrm{NC}$ & $\mathrm{NC}$ & $(-)$ & $\mathrm{NC}$ \\
\hline P2D-04/16 & $\mathrm{NC}$ & NA & $\mathrm{NC}$ & $\mathrm{NC}$ & $\mathrm{NC}$ & $(-)$ & $\mathrm{NC}$ \\
\hline P2R-10/16 & 170 & 2800 & $\mathrm{NC}$ & $\mathrm{NC}$ & 220 & 35 & 160 \\
\hline P2R-02/17 & $<1$ & $<1$ & $\mathrm{NC}$ & $\mathrm{NC}$ & $\mathrm{NC}$ & $\mathrm{NC}$ & $\mathrm{NC}$ \\
\hline
\end{tabular}




\begin{tabular}{|c|c|c|c|c|c|c|c|}
\hline $\begin{array}{l}\text { Points } \\
\text { DATES }\end{array}$ & $\begin{array}{l}\text { Thermo- } \\
\text { tolerant } \\
\text { Coliforms }\end{array}$ & $\begin{array}{c}\text { Total } \\
\text { Coliforms }\end{array}$ & Salmonella & Clostridium & $\begin{array}{l}\text { Hetero- } \\
\text { trophic } \\
\text { bacteria }\end{array}$ & $\begin{array}{l}\text { Stafhylo } \\
\text { coccus } \\
\text { aureus }\end{array}$ & $\begin{array}{l}\text { Sulfite } \\
\text { reducing } \\
\text { Bacteria }\end{array}$ \\
\hline Units & \multicolumn{2}{|l|}{ MPN/100mL } & \multicolumn{5}{|l|}{$\mathrm{CFU} / \mathrm{mL}$} \\
\hline P2R-08/17 & $<1$ & $<1$ & $\mathrm{NC}$ & $\mathrm{NC}$ & 1000 & 35 & $\mathrm{NC}$ \\
\hline P3D-12/15 & $\mathrm{NC}$ & NA & $\mathrm{NC}$ & NC & 100 & $(-)$ & $\mathrm{NC}$ \\
\hline P3D-04/16 & $\mathrm{NC}$ & NA & $\mathrm{NC}$ & $\mathrm{NC}$ & $\mathrm{NC}$ & $\mathrm{NC}$ & $\mathrm{NC}$ \\
\hline P3R-10/16 & 280 & 2400 & $\mathrm{NC}$ & $\mathrm{NC}$ & 320000 & 20 & 230 \\
\hline P3R-02/17 & $<1$ & $<1$ & $\mathrm{NC}$ & $\mathrm{NC}$ & $\mathrm{NC}$ & $\mathrm{NC}$ & $\mathrm{NC}$ \\
\hline P3R-08/17 & $<1$ & $<1$ & $\mathrm{NC}$ & $\mathrm{NC}$ & 100 & $\mathrm{NC}$ & $\mathrm{NC}$ \\
\hline P4D-12/15 & $\mathrm{NC}$ & NA & $\mathrm{NC}$ & $\mathrm{NC}$ & 1.000 & $(-)$ & $\mathrm{NC}$ \\
\hline P4D-04/16 & 92 & NA & $\mathrm{NC}$ & $\mathrm{NC}$ & 50 & $\mathrm{NC}$ & $\mathrm{NC}$ \\
\hline P4R-02/17 & $<1$ & $<1$ & $\mathrm{NC}$ & $\mathrm{NC}$ & $\mathrm{NC}$ & $\mathrm{NC}$ & $\mathrm{NC}$ \\
\hline P4R-08/17 & $<1$ & $<1$ & $\mathrm{NC}$ & $\mathrm{NC}$ & 100 & $\mathrm{NC}$ & $\mathrm{NC}$ \\
\hline P5D-12/15 & $\mathrm{NC}$ & NA & $\mathrm{NC}$ & $\mathrm{NC}$ & 100 & $(-)$ & $\mathrm{NC}$ \\
\hline P5D-04/16 & $\mathrm{NC}$ & NA & $\mathrm{NC}$ & $\mathrm{NC}$ & $\mathrm{NC}$ & $\mathrm{NC}$ & $\mathrm{NC}$ \\
\hline P5R-02/17 & $<1$ & $<1$ & $\mathrm{NC}$ & $\mathrm{NC}$ & $\mathrm{NC}$ & $\mathrm{NC}$ & $\mathrm{NC}$ \\
\hline P5R-08/17 & $<1$ & $<1$ & $\mathrm{NC}$ & $\mathrm{NC}$ & 100 & $\mathrm{NC}$ & $\mathrm{NC}$ \\
\hline P6D-12/15 & $\mathrm{NC}$ & NA & $\mathrm{NC}$ & $\mathrm{NC}$ & $\mathrm{NC}$ & $(+)$ & $\mathrm{NC}$ \\
\hline P6D-04/16 & 1.100 & NA & $\mathrm{NC}$ & $\mathrm{NC}$ & $\mathrm{NC}$ & $100(+)$ & $\mathrm{NC}$ \\
\hline P6R-10/16 & 3.600 & 320.000 & $\mathrm{NC}$ & $\mathrm{NC}$ & 380000 & 35 & 110 \\
\hline P6R-02/17 & $<1$ & $<1$ & $\mathrm{NC}$ & $\mathrm{NC}$ & $\mathrm{NC}$ & $\mathrm{NC}$ & $\mathrm{NC}$ \\
\hline P6R-08/17 & $<1$ & $<1$ & $\mathrm{NC}$ & $\mathrm{NC}$ & 100 & $\mathrm{NC}$ & $\mathrm{NC}$ \\
\hline P7D-12/15 & $\mathrm{NC}$ & NA & $\mathrm{NC}$ & $\mathrm{NC}$ & $\mathrm{NC}$ & $(-)$ & $\mathrm{NC}$ \\
\hline P7D-04/16 & 460 & NA & $\mathrm{NC}$ & $\mathrm{NC}$ & 100 & $11(+)$ & $\mathrm{NC}$ \\
\hline P7R-10/16 & 60 & 110 & $\mathrm{NC}$ & $\mathrm{NC}$ & 2300 & $(-)$ & 2.300 \\
\hline P7R-02/17 & $<1$ & $<1$ & $\mathrm{NC}$ & $\mathrm{NC}$ & $\mathrm{NC}$ & $\mathrm{NC}$ & $\mathrm{NC}$ \\
\hline P8D-12/15 & $\mathrm{NC}$ & NA & $\mathrm{NC}$ & $\mathrm{NC}$ & $\mathrm{NC}$ & $(+)$ & 3.900 \\
\hline P8D-04/16 & 1.100 & NA & $\mathrm{NC}$ & $\mathrm{NC}$ & $\mathrm{NC}$ & $13(+)$ & $\mathrm{NC}$ \\
\hline P8R-10/16 & 220 & 2.400 & $\mathrm{NC}$ & $\mathrm{NC}$ & 3400 & $(-)$ & 80 \\
\hline P8R-02/17 & $<1$ & $<1$ & $\mathrm{NC}$ & $\mathrm{NC}$ & $\mathrm{NC}$ & $\mathrm{NC}$ & $\mathrm{NC}$ \\
\hline P8R-08/17 & $<1$ & $<1$ & $\mathrm{NC}$ & $\mathrm{NC}$ & 100 & $\mathrm{NC}$ & $\mathrm{NC}$ \\
\hline P9R-10/16 & 140 & 2.700 & $\mathrm{NC}$ & $\mathrm{NC}$ & 2600 & $(-)$ & 450 \\
\hline P9D-02/17 & $<1$ & $<1$ & $\mathrm{NC}$ & $\mathrm{NC}$ & $\mathrm{NC}$ & $\mathrm{NC}$ & $\mathrm{NC}$ \\
\hline P9R-08/17 & $<1$ & $<1$ & $\mathrm{NC}$ & $\mathrm{NC}$ & 100 & $\mathrm{NC}$ & $\mathrm{NC}$ \\
\hline P10R-10/16 & 110 & 2.200 & $\mathrm{NC}$ & $\mathrm{NC}$ & 31000 & 210 & 2800 \\
\hline P10D-02/17 & $<1$ & $<1$ & $\mathrm{NC}$ & $\mathrm{NC}$ & $\mathrm{NC}$ & $\mathrm{NC}$ & $\mathrm{NC}$ \\
\hline P10R-08/17 & $<1$ & $<1$ & $\mathrm{NC}$ & $\mathrm{NC}$ & 1000 & $\mathrm{NC}$ & $\mathrm{NC}$ \\
\hline
\end{tabular}

MPN/100mL: Most Probable Number per 100 mL; NC: No Colonies; NA: Not Analyzed; PC: Collecting Point in the Rainy Period; PD: Collecting Point in the Dry period. // Source: The Author. 
The occurrences may be associated to a possible contamination of the wells by the water that percolates during the rainy periods. It was found that percolation is the factor that contributes most to altering the microbiological quality of water, especially groundwater. During the field trips made in the rainy season, it was possible to see the movement of insalubrious materials by rainwater runoff as most of the wells are located in areas with a deficiency of basic sanitation and the wells are constructed without any sanitary control whatsoever.

Thermotolerant coliforms serve as water quality indicators and to establish the parameters of the quality of surface water, groundwater and potable water specified in the respective legislation, according to the use the water is destined for. Their presence expresses the possible contamination of the water by pathogens of fecal origin. In research carried out in Mexico, Gonzáles (1982) observed that the presence of coliforms in the samples of water collected from the sources investigated was directly related to the rainy season due to the conveyance of human and animal excreta. The coliform species belong to the family Enterobacteriaceae (enteric bacteria) that inhabit the intestinal tracts of humans and other animals. The family includes Escherichia coli, Enterobacteraerogenes and Klebsiella pneumoniae (FRANCO et al., 2015).

Determining the presence of heterotrophic bacteria is another important instrument for conducting bacteriological control as it assists in assessments of hygienic conditions and the protection of the wells. These bacteria use organic materials or compounds as a source of carbon for the synthesis of cellular material and growth (TORTORA et al., 2012). Brazilian Ministry of Health Edict 2914/2011 recommends that the maximum acceptable level of mesophilic heterotrophic bacteria cultivated from samples of water for human consumption is $500 \mathrm{CFU} / \mathrm{mL}$ (BRASIL, 2011).

The quantities of total coliforms, thermotolerant coliforms and heterotrophic bacteria in the samples taken at points P3 and P6 in October 2016 were well above the recommended maximums. That may have been due to the fact that animals are raised in the areas surrounding those particular wells; researchers observed their excrements everywhere, and in the rainy periods they are carried along by the waters.

The majority of heterotrophic bacteria are not pathogens. However, there are some members of that group such as Legionella spp, Micobacterium spp, Pseudomonas spp and Aeromonas spp that can become opportunistic pathogens. That means monitoring the quantity of those microorganisms is highly important because when they are present in great numbers in the water they constitute a health risk for whoever drinks it. Furthermore, their presence in abundance degrades the quality of the water; the water changes color and acquires an unpleasant taste and smell and slime may be formed (CETESB, 2011; MELO et al., 2017).

A considerable portion (21\%) of the samples tested positively for the presence of Staphylococcus aureos even though, in the interviews, none of the families associated any diseases to the well water. However, the families at P6 and P7 reported suffering skin itchiness after bathing with that water.

Staphylococcus aureos is part of the natural microbiota. The genus Staphylococcus 
that it belongs to consists of Gram positive bacteria. They are round in shape with diameters from 0.5 to $1.5 \mu \mathrm{m}$ and they may exist as isolated individuals or linked in pairs, or in short chains or in bunches like bunches of grapes. They are immobile, non-sporulating, usually non-capsulated and catalase positive (KONEMAN et al., 1997; OLIVEIRA et al., 2015).

The sulfite reducing clostridia bacteria were found in samples from 7 of the 10 wells. They tend to occur when the $\mathrm{pH}$ of the water is in the range 6 to 7.5 as was the case with the samples in this study. That $\mathrm{pH}$ favors bacteria of animal origin that prefer waters with a $\mathrm{pH}$ higher than 5 .

The results of this research corroborate those obtained by other authors such as Brun et al. (2016); Santos et al. (2015); Capp et al. (2012); Conicelli (2014) and Camargo (2009) who relate microbiological contamination to factors associated to the absence of sanitation in practices such as digging wells in areas where there are septic tanks nearby, or areas where solid waste is being discharged on the ground in the open air. That set of problems could be what is jeopardizing the water table during the rainy periods showing that even though microbiological contamination may occur in locations far apart, they are locations with similar characteristics.

Those conditions can increase the risk of water-borne diseases for the populations that drink untreated shallow-well water from wells constructed without adequate structures. To counter that negative situation, it is necessary to implement the Federal Law on Basic Water Supply and Sanitation n ${ }^{\circ}$ 11.445/07 which:

Addresses the set of services embracing public potable water supply;
collection, treatment and final disposal of wastewater; drainage and
management of urban rainwater in addition to urban cleaning services
and solid waste management.

\section{Socio-environmental problems of the Aracaju Expansion Zone}

Due to the rapid urban transformations that have occurred in Aracaju, it is important to gain an understanding of the local vulnerabilities and limitations as well as the natural potential that could improve the land settlement and environmental occupation patterns in the Aracaju Expansion Zone (ARAÚJO, 2006; BRASIL, 2008; FONSECA et al., 2013).

The area in question, with its fragile [environmental] equilibrium has not been provided with sanitary infrastructure compatible with an urban densification. In the rainy season there is flooding of some of the residences and that is not only due to the densification of human occupation but also to the use made of the former swamp areas that have been filled with earth for the construction of new houses, blocking the natural drainage system for rainwater runoff (WANDERLEY; GONÇALVES, 2005; FONSECA; GONZAGA JÚNIOR, 2010).

The area of this study was instituted by Municipal Law № 873/82 and in spite of the deficiencies mentioned above in regard to basic infrastructure, water supply and 
sanitation, electricity supply, sewage system and social equipment required to meet the necessities, it has attracted residential segments, condominiums and isolated housing plots which according to IBGE statistics presented a growth of 33\% from 1991 to 1996 and by the year 2000 there was an estimated population of 15,000 inhabitants within an overall population count for the city of Aracaju of 461,534 at that time. In the last 30 years the Aracaju Expansion Zone has received a further 22,702 inhabitants bringing with them demands for additional housing in a process which ought to be accompanied by the public administration in regard to infrastructure and public services support (NOGUEIRA, 2004).

That fact, exacerbated by the tendentious scenario of population growth, the persistence of the infrastructure problems and the adverse socioenvironmental conditions in the area under study, will continue to foster the increasing incidence of diseases unless steps are taken to reverse the tendency, especially in regard to wells that are installed in the proximity of septic tanks and domestic wastewater that drains into the sandy soils and contaminates the wells. The situation is made even worse by the existence of clandestine cemeteries in the same area (BRASIL, 2009; REZENDE, 2010; SOARES, 2012; SANTOS et al., 2015).

In her analysis of the relation between time of residence at the same address of the persons being interviewed and the changes they had observed in regard to construction, Soares (2012) found that 69\% reported that many houses were being built in the area, $35 \%$ remarked on the increase in commercial entities, $69 \%$ said that Areas of Permanent Preservation were being used to build houses in, $56 \%$ told how those areas had been cleared of vegetation and also that there were swampy areas surrounding the houses where water accumulates during the rainy season and that the people in the nearby houses use those waters to bathe in and for leisure, especially the children. Here is how one of the interviewees expressed it:

When the rains come, around the houses gets flooded and the water remains in the bush for months. The children play in the water; years ago there were even little fish for everyone to eat (E. 1).

The data show that the residents live in a situation of vulnerability in regard to environmental aspects given that most of the interviewees perceived how the neighborhood had grown in terms of buildings and commerce but, for that growth to happen, the environment suffers the consequences and diseases are on the increase as the following statement reveals:

Many houses are being built in the area of the mangrove swamp which is being filled in (a person in the neighborhood is selling housing lots there); with the rains they get waterlogged and there are many mosquitos in the stagnant water, even so people still fish there (E. 2).

The fragmentation of the land is brought about by practices such as the production of walled in condominiums and of low-income housing projects far from the city center creating new environments for housing. That is where the question of state intervention 
comes in, resuscitating the discussions regarding the great disparity in the public investments made in the different areas of the city. It is also necessary to evaluate government's performance in the regulatory aspect when it is planning certain future scenarios based on urbanistic indexes. There is a notable divergence between the urban planning with its Master Plan and guidelines and the environmental reality of the area (FRANÇA, 2016).

\section{CONCLUSION}

Given the threat to public health constituted by water-borne diseases, it is essential to ensure the good quality of the water that the population consumes.

Inadequate practices such as constructing shallow wells in places where there are septic tanks, open air waste dumps and an absence of sewage systems leads to contamination of water through the survival and multiplication of microorganisms, especially bacteria. Consequently, improving the condition of water systems that capture water from domestic wells, and raising the populations' awareness in regard to the factors that lead to water contamination and jeopardize the quality of the water would certainly reduce the incidence of diseases caused by water-borne pathogens.

In the dry season it was possible to verify that the groundwater is not influenced by local land use patterns because most of samples collected during the period presented no bacteria counts. In the rainy season however, the water of 09 out of 10 wells that were analyzed were considered unfit for human consumption as the concentrations of total coliforms, thermotolerant coliforms, heterotrophic bacteria, Stafhylococus aureus and sulfite-reducing bacteria extrapolated the legally established parameters. Thus the water from the wells the community in the Aracaju Expansion Zone depends on is not free from bacterial contamination and constitutes a health risk for those who use it.

\section{References}

ANA - AGÊNCIA NACIONAL DE ÁGUAS. Indicadores de qualidade - índice de qualidade das águas (IQA). Portal da Qualidade das Águas, 2014. Available at: http://portalpnqa.ana.gov. br/indicadores-indice-aguas.aspx. Retrieved on: July 18, 2017.

ANA/CETESB. Guia nacional de coleta e preservação de amostras - Água, sedimento, comunidades aquáticas e efluentes líquidos. Agência Nacional das Águas/Companhia Ambiental do Estado de São Paulo, Brasília: ANA, 2011, 325p. 2.

APHA - AMERICAN PUBLIC HEALTH ASSOCIATION. Standard methods for the examination of water and wastewater. 22르 ed. Washington: American Public Health Association/ American Water Works Association/Water Pollution Control Federation, 2012.

BARRELL, R. et al. The microbiology of drinking water: water quality and public health. Environment agency, 2002.

BRASIL. Mistério da Saúde. Secretaria de vigilância em saúde departamento de DST, Aids e 
Hepatites Virais. Boletim epidemiológico hepatites virais. Brasília, 2012.

BRASIL. Ministério da saúde. Portaria no 2.914, de 12 de dezembro de 2011. Dispõe sobre os procedimentos de controle e de vigilância da qualidade da água para consumo humano e seu padrão de potabilidade. Diário oficial da República Federativa do Brasil. Brasília, DF, 12 dez. 2011.

BRASIL. Ministério da Saúde. Secretaria de Vigilância em Saúde. Guia de Vigilância em Saúde. Brasília, 2014. $812 \mathrm{p}$

BRASIL. Trata Brasil. Available at: http://www.tratabrasil.org.br/saneamento-nobrasil. Retrieved on: August 22, 2017.

BRUN, B. R. et al. Qualidade das Águas de Poços Rasos em Área com Déficit de Saneamento Básico em Cuiabá, MT: Avaliação Microbiológica, Físicoquímica e Fatores de Risco à Saúde. HOLOS, v. 2, n. 32, p. 179-188, 2016.

CAMARGO, M. F; PAULOSSO, L. V. Avaliação qualitativa da contaminação microbiológica das águas de poços no município de Carlinda - MT. Semina: Ciências Biológicas e da Saúde, Londrina, v. 30, n. 1, p. 77-82, Jan./Jun. 2009.

CAPP, N.; AYACH, L. R.; SANTOS, T. M. B.; GUIMARÃES, S. T. L. Qualidade da água e fatores de contaminação de poços rasos na área urbana de Anastácio (MS). Revista Meio Ambiente, Paisagem e Qualidade Ambiental. v. 16, n.3, p. 77-91, 2012.

CONICELLI, B. P. Gestão das Águas Subterrâneas na Bacia Hidrográfica do Alto Tietê. 2014. 163 f. Ph.D. Thesis - Universidade de São Paulo, São Paulo, 2014.

DREYFUS, A. et al. Leptospira Seroprevalence and Risk Factors in Health Centre Patients in Hoima District, Western Uganda. PLOS Neglected Tropical Diseases, v. 10, n. 8, p. 1-14, 2016.

FAVRE, T. C. et al. School-based and community-based actions for scaling-up diagnosis and treatment of schistosomiasis towards its elimination in an endemic area of Brazil. Acta Trop. v. 149 , p. $155-162$, Sep/2015.

FONSECA, V.; SOARES, A. C. G. M. POLÍTICAS PÚBLICAS E DIREITOS HUMANOS: IMPACTOS PROVOCADOS PELA OCUPAÇÃO IRREGULAR NA ZONA DE EXPANSÃO DE ARACAJU, ESTADO DE SERGIPE. Interfaces Científicas - Humanas e Sociais, v .1, n. 2, p. 81-87, 2013.

FRANÇA, I. S. Planejamento urbano e participação social em cidade média: a revisão do plano diretor de Montes Claros-MG. GeoTextos, v. 12, n. 2, p. 107-134, Dez. 2016.

FRANCO, G.B. et al. AVALIAÇÃO DA QUALIDADE SANITÁRIA DA ÁGUA NA BACIA HIDROGRÁFICA DO RIO ALMADA - BA. Caminhos de Geografia. v. 16, n. 54, p. 254-262, Jun/2015.

GONZÁLES, R. G.; TAYLOR, M.L.; ALFARO, G. Estudo bacteriano del água de consumo en uma comunidad. Mexicana. Bol. Oficina Sanit. Panam., v. 93, n. 2, p. 127-141, 1982.

Google Earth 2017 - Live 3D Maps \& Satellite Map - ubersearch.biz. Available at: www.ubersearch.biz/earth/map Earth Map 2017. Retrieved on: July 14, 2017.

KONEMAN, E. W. et al. The gram-positive cocci: Staphylococci and related organisms. Atlas 
and Textbook of Diagnostic Microbiology, Philadelphia, 1997. p.539-576.

MARENGO, J. A., Água e mudanças climáticas. Estudos Avançados. Brasília, v. 22, n. 63, 2008.

MELO, Y. C.; MONTES, A. M.; OLIVEIRA, E. J. A. Avaliação da qualidade de "água mineral natural” e a relevância da análise de bactérias heterotróficas. Revista CIENTEC. v. 9, n 1, p.181-189, 2017.

OLIVEIRA, D. B. et al. Caracterização de Staphylococcus aureus isolados da barra de mão de carrinhos e alças de cestas de supermercados. Rev Ciênc Farm Básica Apl. v. 36, n. 3, p. $407-$ 412, 2015.

SANTOS, A. G. S; MORAES, L. R. S.; NASCIMENTO, S. A. M. Qualidade da água subterrânea e necrocorume no entorno do cemitério do Campo Santo em Salvador-BA. Revista Eletrônica de Gestão e Tecnologias Ambientais. v. 3, n. 1, p. 39-60, 2015.

SNIS - SISTEMA NACIONAL DE INFORMAÇÕES SOBRE SANEAMENTO. Diagnóstico dos serviços de água e esgotos. Brasília, 2017.

SILVA, M. C. A. et al. Evaluation of the viability of using coliphages as indicators of fecal pollution: relations with physical and chemical parameters and bacterial indicators. Eng. Sanit. Ambient. v. 20, n.4, Rio de Janeiro, Oct./Dec. 2015.

SOARES, A. C. G. M. Doenças de notificação compulsória: saúde e ambiente na zona de expansão urbana de Aracaju. 2012. 102 f. Dissertação de mestrado - Universidade Tiradentes, Programa de Pós-Graduação em Saúde e Ambiente, Aracaju, 2012.

SOARES, T. C. et al. Perfil da água para o consumo humano e notificação de doenças em uma macrorregião do Piauí, Brasil. Revista Brasileira de Higiene e Sanidade Animal, v.12, n.2, p. 205 -215, abr.jun. 2018.

SOUZA, T. G. S. Água potável garantia de qualidade de vida. 2014. 16 f. Universidade Federal do Piauí, Piuaí, 2014.

TORTORA, G. J.; FUNKE, B.R.; CASE, C.L. (2012) - Microbiologia. $10^{\circ}$ ed. Porto Alegre, Artmed, 934 p.

UNESCO. Water for a Sustainable Word. Paris: 2015.

World Health Organization (WHO). 2100 millones de personas carecen de agua potable en el hogar y más del doble no disponen de saneamiento seguro. Available at: who.int/mediacentre/ news/releases/2017/water-sanitationhygiene/es/. Retrieved in August, 2017. 


\section{Ana Celia Goes Melo Soares}

๑anaceliagoes@hotmail.com

ORCiD: https://orcid.org/0000-0001-7993-7784
Submitted on: 24/10/2017

Accepted on: 03/06/2020

2020;23:e02561

\title{
Rômulo André Santos Silva
}

$\square$ romuloandre_555@hotmail.com

ORCiD: https://orcid.org/0000-0003-1127-1407

Carla Viviane Freitas de Jesus

$\square$ carlavfj@gmail.com

ORCiD: https://orcid.org/0000-0002-7775-6610

\section{Roneval Felix Santana}

$\square$ roneval_felix@hotmail.com

\author{
Álvaro Silva Lima \\ $\square$ alvaro_lima@itp.org.br \\ ORCiD: https://orcid.org/0000-0002-0603-8187
}

\section{Sonia Oliveira Lima}

$\square$ sonialima.cirurgia@gmail.com

ORCiD: https://orcid.org/0000-0002-3257-2412

\section{Maria Nogueira Marques}

$\square$ mnogueiramarques@yahoo.com.br

ORCiD: https://orcid.org/0000-0002-4716-4569

How to cite: SOARES, et. al. Water and health risk assessment in the Aracaju Expansion Zone - SE. Ambiente \& Sociedade. São Paulo, v. 23, p. 1-15, 2020. 


\title{
Avaliação da água e o risco à saúde na Zona de Expansão de Aracaju - SE
}

\author{
Ana Celia Goes Melo Soares \\ Rômulo André Santos Silva \\ Carla Viviane Freitas de Jesus \\ Roneval Felix Santana \\ Álvaro Silva Lima \\ Sonia Oliveira Lima \\ Maria Nogueira Marques
}

São Paulo. Vol. 23, 2020

Artigo Original
Resumo: A Zona de Expansão de Aracaju apresenta problemas relacionados à falta de água em condições adequadas de quantidade e qualidade. $\mathrm{O}$ poder aquisitivo da comunidade nativa do local levou a população a construir poços rasos em suas residências para garantir o abastecimento de água, única alternativa para consumo doméstico, sem tratamento prévio. $\mathrm{O}$ objetivo deste trabalho foi avaliar a qualidade da água de poços e os cenários de risco à saúde, por meio das análises microbiológicas. As coletas foram realizadas no período de dezembro de 2015 a agosto de 2017, de acordo com a metodologia estabelecida pelo Standand Methods for the Examination of Water \& Wastewater, 21 ed. Concluiu-se que o período chuvoso apresentou contaminação, por coliformes, bactérias heterotróficas, Staphylococcus aureos e bactérias sulfitos redutoras, enquanto que no período de seca a maioria das amostras não apresentou contagem bacteriológica. $\mathrm{O}$ consumo dessas águas representa risco à saúde da população.

Palavras-chave: Análise microbiológica, Saúde Pública, Sergipe, Nordeste.

Como citar: SOARES, et. al. Avaliação da água e o risco à saúde na Zona de Expansão de Aracaju - SE. Ambiente $\mathbb{\&}$ Sociedade. São Paulo, v. 23, p. 1-16, 2020.

DOI: http://dx.doi.org/10.1590/1809-4422asoc20170256r1vu2020L4AO 


\title{
Evaluación del agua y riesgo para la salud en la zona de expansión de Aracaju - SE
}

\author{
Ana Celia Goes Melo Soares \\ Rômulo André Santos Silva \\ Carla Viviane Freitas de Jesus \\ Roneval Felix Santana \\ Álvaro Silva Lima \\ Sonia Oliveira Lima \\ Maria Nogueira Marques
}

São Paulo. Vol. 23, 2020

Artículo original
Resumen: La Zona de Expansión de Aracaju presenta problemas relacionados con la falta de agua en condiciones adecuadas de cantidad y calidad. El poder adquisitivo de la comunidad nativa del lugar llevó a la población a construir pozos en sus hogares para garantizar el abastecimiento del agua potable sin tratamiento previo. El objetivo de este trabajo fue evaluar la calidad del agua de pozos y los riesgo a la salud, a través de los análisis microbiológicos. Los muestreos se realizaron de diciembre de 2015 a agosto de 2017, de acuerdo con la metodología establecida por el Standand Methods for the Examination of Water \& Wastewater, 21 ${ }^{\mathrm{a}}$ ed. El período lluvioso presentó contaminación por coliformes, bacterias heterotróficas, Staphylococcus aureos y bacterias sulfitos reductoras, mientras que en el período de sequía la mayoría de las muestras no apreseció recuento bacteriológico. El consumo de estas aguas representa riesgo para la salud de la población.

Palabras-clave: Análisis microbiológico, Salud Pública, Sergipe, Nordeste.

Como citar: SOARES, et. al. Avaliação da água e o risco à saúde na Zona de Expansão de Aracaju - SE. Ambiente $\mathbb{\&}$ Sociedade. São Paulo, v. 23, p. 1-15, 2020.

DOI: http://dx.doi.org/10.1590/1809-4422asoc20170256r1vu2020L4AO 